\title{
УДК 351.751-042.3:316.334:316.42
}

Дакал Алла Василівна доктор наук 3 державного управління, доцент кафедри публічного адміністрування Навчально-наукового інституту міжнародних відносин та соціальних наук ПрАТ "Вищий навчальний заклад "Міжрегіональна Академія управління персоналом", 03039 Київ, вул. Фрометівська, 2, тел.+380678904646, email: a_dakal@nuozu.edu.ua, https//orcid.org/0000-0003-3221-353X

\section{ВПЛИВ ДЕРЖАВНОЇ ПОЛІТИКИ УКРАЇНИ НА РОЗВИТОК ГРОМАДЯНСЬКОГО СУСПІЛЬСТВА: РЕТРОСПЕКТИВНИЙ АНАЛІЗ}

Анотація. Стаття присвячена розгляду сучасних наукових підходів до проблематики впливу державної політики України на розвиток громадянського суспільства, механізмів взаємодії та співробітництва між органами публічної влади та інституціями громадянського суспільства. Визначено роль інституцій громадянського суспільства як ключового елементу формування демократичного політичного режиму, виразника суспільної думки та системи суспільно-владних й позадержавних суспільних відносин та інститутів, що дає можливість людині реалізувати ії громадянські права різноманітні потреби, інтереси та цінності.

Обгрунтовано, що завдання й функції держави на сучасному етапі демократизації зумовлюють i новий зміст управлінської діяльності органів публічного врядування, визначають особливості функціонування механізмів державного управління, вироблення та реалізації державної політики, яка спирається на розвинене громадянське суспільство та взаємодіє з його інституціями.

Розкрито проблеми та причини неефективності державного сприяння розвитку громадянського суспільства в Україні. Охарактеризовано напрямки сприяння розвитку громадянського суспільства в Україні на найближчі п'ять років, закріплені Указом Президента України "Про сприяння розвитку громадянського суспільства в Україні” Національної стратегії сприяння розвитку громадянського суспільства в Україні на 2016-2020 роки.

Зроблено висновок, що в сучасному науково-практичному розумінні демократичне державотворення $є$ невіддільним від громадянського суспільства. Відтак сприяння всебічному розвитку громадянського суспільства $є$ важливою функцією й завданням демократичної держави, ії органів публічного врядування в частині налагодження ефективної співпраці та взаємодії державних органів і установ з різноманітними інституціями громадянського суспільства.

Ключові слова: держава, державна політика, громадянське суспільство.

Dakal Alla Vasylivna D.Sc. of Public Administration, Associate Professor Department of Public Administration Educational-Scientific Institute of International Relations and Social Sciences Private higher education institution "Interregional Academy of Personnel Management", 03039 Kyiv, street Frometivska, 2, tel.+380678904646, email: a_dakal@ nuozu.edu.ua, https//orcid.org/0000-0003-3221-353X 


\title{
THE INFLUENCE OF UKRAINE'S STATE POLICY ON THE DEVELOPMENT OF CIVIL SOCIETY: A RETROSPECTIVE ANALYSIS
}

\begin{abstract}
The article is devoted to the consideration of modern scientific approaches to the issue of the influence of the state policy of Ukraine on the development of civil society, mechanisms of interaction and cooperation between public authorities and civil society institutions. The role of civil society institutions as a key element in the formation of a democratic political regime, the expression of public opinion and the system of public and non-state social relations and institutions, which enables a person to realize his civil rights, various needs, interests and values.

It is substantiated that the tasks and functions of the state at the present stage of democratization determine the new content of administrative activities of public authorities, determine the features of the mechanisms of public administration, development and implementation of public policy based on developed civil society and interacts with its institutions.

Problems and reasons for the inefficiency of state support for the development of civil society in Ukraine are revealed. The directions of promoting the development of civil society in Ukraine for the next five years, enshrined in the Decree of the President of Ukraine "On promoting the development of civil society in Ukraine" National Strategy for promoting civil society in Ukraine for 2016-2020.

It is concluded that in the modern scientific and practical sense, democratic state formation is inseparable from civil society. Therefore, promoting the comprehensive development of civil society is an important function and task of a democratic state, its public authorities in terms of establishing effective cooperation and interaction of state bodies and institutions with various civil society institutions.
\end{abstract}

Keywords: state, state policy, civil society.

Постановка проблеми. Демократичне державотворення в Україні передбачає, насамперед, ціннісну трансформацію суспільно-владних відносин у напрямку формування людиноцентричної гуманітарної парадигми публічного врядування нашої країни. Як зазначає I. Гордієнко "ефективний вплив держави на становлення громадянського суспільства в Україні безпосередньо залежить від якісної трансформації політичної системи, змін у моделі державного управління в напрямку децентралізації, послаблення неефективних адміністративнокомандних та суто регулятивних методів тощо" [3, с. 34]. Нові завдання й функції держави на сучасному етапі демократизації зумовлюють i новий зміст управлінської діяльності органів публічного врядування, визначають особливості функціонування механізмів державного управління, вироблення та реалізації державної політики. У цьому контексті, як свідчить світова практика, неможливо обійтися без опору на розвинене громадянське суспільство. Жодна держава неспроможна без співучасті інституцій громадянського суспільства створити можливості для функціонування демократичного державно-владного режиму, забезпечення функціонування демократії участі, що у поєднанні 3 безпосередньою та представницькою демократією $є$ основою успішної модернізації та сталого розвитку суспільства і держави. 
У сучасних умовах процес становлення в Україні громадянського суспільства ускладнюється політичною нестабільністю, етнічною конфліктогенністю, невисоким рівнем громадянської ініціативи основної частини населення. Виклики, що постають нині перед нашою державою, - наголошує Л. Родченко - вимагають дієвого та результативного залучення інституцій громадянського суспільства до постійного діалогу з органами державної влади усіх рівнів. Це не данина суспільній чи політичній, адміністративній чи державницькій моді; це, по-перше, першооснова успішності щоденної діяльності державного апарату, спрямованої на забезпечення позитивного соціального самопочуття українців, заради яких державна машина і покликана функціонувати ефективно. По-друге, це - виклик сьогодення, оскільки держава як орган макроуправління здатна виконувати свої основні функції лише в поєднанні та взаємодії з процесами самоорганізації і самоуправління на рівні суспільства й соціальних груп [14, с. 157].

Аналіз останніх досліджень і публікацій. Світовий та вітчизняний дискурс розуміння й тлумачення дихотомії "держава - громадянське суспільство" налічує сотні публікацій та дискусій, що точаться вже понад півстоліття. При цьому західна політична думка тяжіє до розгляду громадянського суспільства як основного засобу захисту свободи індивіда від надмірної опіки державних органів. Передовий європейський досвід вивчення громадянського суспільства показує, що його сформованості відбиває ступінь розвитку демократії. В Україні накопичено значний обсяг наукових праць у контексті розгляду генези феномену громадянського суспільства, його основних інституціональних складових та способів взаємодії з державою у процесі формування політичних відносин на новій, демократичній основі. При цьому у вітчизняній науці проблематика громадянського суспільства здебільшого вивчається через взаємодію його 3 державною владою. Зокрема, тільки останніми роками активно працюють у зазначеній проблематиці такі науковці як. Т. Андрійчук [1], Н. Бондаренко [2], С. Волинець [3], І. Гордієнко [5], М. Канавець [8], О. Радченко [11, 12], С. Погорелий [12], Л. Родченко [13, 14], О. Турій [15]. Проте, незважаючи на доволі глибоке опрацювання проблематики взаємодії держави та громадянського суспільства у вітчизняній науці все ще залишаються недостатньо опрацьованими питання впливу державної політики України на розвиток громадянського суспільства та механізмів взаємодії й співробітництва між органами публічної влади та інституціями громадянського суспільства.

Все це надзвичайно актуалізує зростання наукового інтересу до аналізу й розкриття проблематики впливу державної політики України на розвиток громадянського суспільства, механізмів взаємодії та співробітництва між органами публічної влади та інституціями громадянського суспільства, що й становить мету та завдання даної наукової розвідки.

Виклад основного матеріалу. Громадянське суспільство - продукт історичного розвитку людства, який пов'язують 3 виникненням інституту приватної власності. Обов'язковою умовою виникнення громадянського суспільства $є$ поява можливості громадян отримання економічної самостійності на базі приватної власності. Найважливішою передумовою формування 
громадянського суспільства є ліквідація станових привілеїв і зростання значення особистості, яка перетворюється 3 підданого на громадянина 3 рівними юридичними правами з усіма іншими громадянами.

В історії державно-політичної думки ідея громадянського суспільства походить від Стародавньої Греції та античного Риму. Проте наукові підвалини сучасного бачення інституту громадянського суспільства та його ролі в державно-організованому бутті соціуму закладені, насамперед, у вченнях I. Канта та Г. Ф. Гегеля.

Так, німецький філософ І. Кант стверджував, що формування громадянського суспільства становить собою головний шлях поєднання свободи кожного індивіда із свободою інших. Він висунув актуальні донині принципи функціонування громадянського суспільства: а) свобода кожного члена суспільства; б) рівність його 3 будь-яким іншим членом товариства; в) самостійність як громадянина [9, с. 43]. I. Кант наголошував, що в умовах громадянського суспільства громадянин має володіти тією ж можливістю примусу державних службовців до точного i бездоганного виконання закону, якою володіє й апарат державної служби у його ставленні до громадянина.

Безпосереднім автором концепції громадянського суспільства $є$ Г. Ф. Гегель. Мислитель у широко відомій роботі «Філософія права» розглядав громадянське суспільство як середовищну форму людської спільності, що розташовується між сім'єю та державою та забезпечує життєздатність суспільства та реалізацію цивільних прав громадян [4, с. 38]. Саме Гегель обгрунтував поняття громадянського суспільства не лише як сукупності індивідів та відносин між ними, а й як сфери діяльності різноманітних громадських інститутів. Громадянське суспільство при цьому являє собою не механічну сукупність індивідів, що зібралися на мить тільки для одиничного тимчасового акту без подальшого зв'язку, а як складна мережа різноманітних рівнопорядкових спілок, організацій, товариств та корпорацій, які таким чином виступають виразниками тих чи інших громадських інтересів та чинять тиск на публічну владу задля реалізації таких інтересів і прав людини й громадянина. [там само, с. 44].

Основи сучасного розуміння громадянського суспільства заклали Дж. Александер, Е. Арато та Дж. Коген, Т. Парсонс, Г. О’Доннелл, Т. Карозерс, Дж. Кін, Дж. Лінц, В. Меркель, А. Міхнік, Р. Патнем, П. Розанвалон, та інші мислителі першої половини ХХ ст.

Громадянське суспільство в сучасному розумінні є виразником суспільної думки, що є своєрідною формою прояву його політичної влади. Водночас - це сила, що знаходиться 3 державою в постійній складній, суперечливій, діалектичній єдності. В цілому, сутнісною характеристикою громадянського суспільства є своєрідний еклектизм - поєднання та урахування інтересів найрізноманітніших соціальних та політичних сил, що передбачає зіткнення, протиріччя, конфлікти між ними, що доповнюються протиріччями між приватними та державними інтересами.

Таким чином, громадянське суспільство - це система суспільно-владних та позадержавних суспільних відносин та інститутів, що дає можливість людині реалізувати іiі громадянські права та виражає різноманітні потреби, інтереси та 
цінності членів суспільства. Але водночас, одним 3 головних призначень громадянського суспільства полягає у досягненні консенсусу між різними соціальними силами та інтересами. Воно покликане визначити норми та межі, здатні блокувати руйнівні потенції боротьби різних сил та спрямовувати іiі у творче русло.

Ретроспективний аналіз впливу держави на розвиток громадянського суспільства свідчить, що у ХX ст. у розвинених країнах сформувався певний тип громадянського суспільства, якому притаманні пріоритет приватної власності і приватновласницьких інтересів, наявність значного «середнього класу», високий рівень життя, велика кількість різноманітних суспільнополітичних організацій, що виражають інтереси різних соціальних груп, своєрідний соціальнопсихологічний і політичний менталітет тощо. Громадянське суспільство виникає там, де визріли передумови громадянського компромісу та світоглядного плюралізму, де складається сукупність суспільних інститутів, що мають власний статус і здатні до рівноправного діалогу 3 інститутом держави, спроможні протистояти політичній експансії держави, бути іiі противагою; стримувати іiі прагнення монополії, перетворення із системи забезпечення розвитку суспільства в систему самозабезпечення.

У країнах, що вступили на шлях глибоких реформ, формується перехідний тип громадянського суспільства, в якому химерно переплітаються деякі властивості і риси як авторитарного, так і демократичного устрою. При цьому варто наголосити, що активність участі громадян у суспільно-політичному житті багато в чому зумовлена станом політичної культури суспільства та авторитарними рудиментами радянського періоду, що досі функціонують в системі державної влади нашої держави. Саме в цьому криються основні проблеми недостатньої зрілості громадянського суспільства в перехідних транзитивних державах, до яких відноситься й Україна. Так, Н. Бондаренко наголошує, що саме "авторитарний спосіб здійснення політичної влади в Україні гальмує процес розвитку громадянського суспільства, що виявляється у формуванні політичних партій під конкретну посадову особу; лобіювання корпоративних інтересів або інтересів бізнесу; переорієнтації ідеології партій залежно від ситуації в суспільстві; створенні альтернативних демократичних об’єднань громадян (наприклад «антимайдан»); нав'язуванні суспільству системи поглядів та ідей окремої правлячої групи; втіленні інтересів правлячої еліти у прийнятих нормативних актах; існуванні керованих владою 3МI" [2, с. 20].

Розуміння основних проблем розвитку громадянського суспільства в Україні демонструє Національна стратегія сприяння розвитку громадянського суспільства в Україні на 2016 - 2020 рр., в якій наголошується, що:

- взаємодія органів державної влади, органів місцевого самоврядування 3 громадськістю залишається малоефективною через недостатню прозорість діяльності цих органів та забюрократизовані процедури такої взаємодії, низький рівень взаємної довіри;

- в Україні відсутній ефективний громадський контроль за діяльністю органів державної влади, органів місцевого самоврядування; 
- недостатньою $є$ практика залучення громадськості до формування та реалізації державної політики і вирішення питань місцевого значення;

- потенціал організацій громадянського суспільства не повною мірою використовується органами виконавчої влади, органами місцевого самоврядування для надання соціальних та інших суспільно значущих послуг;

- благодійники не мають ефективних стимулів з боку держави, зокрема податкових, обтяжені бюрократичними процедурами, відсутній дієвий механізм захисту від шахрайства та інших зловживань у сфері благодійництва;

- більшість організацій громадянського суспільства не має доступу до державної фінансової підтримки через ї̈ обмежений обсяг, незастосування прозорих конкурсних процедур та надання необгрунтованих переваг окремим видам організацій громадянського суспільства;

- відсутня єдина державна інформаційно-просвітницька політика у сфері сприяння розвитку громадянського суспільства [10].

Як зазначають експерти та фахівці Національного інституту стратегічних досліджень, ефективність державного сприяння розвитку громадянського суспільства в Україні все ще залишається недостатньою через низку перешкод, серед яких також називають:

- брак інструментів співпраці органів виконавчої влади 3 інститутами громадянського суспільства, зокрема, відсутність конкретних процедур участі громадських організацій у циклі державного фінансування призводить до спрямування основних бюджетних коштів на вирішення безпосередніх проблем та ситуативних перспектив Уряду без врахування можливостей організацій громадянського суспільства.

- недостатнє державне стимулювання розвитку нових механізмів фінансової підтримки неприбуткових організацій. Необхідність упровадження альтернативних механізмів отримання ОГС доходів, зокрема відсоткової філантропії [7, с. 67-69].

Аналізуючі окреслені проблеми О. Турій конститує, що "зусилля органів державної влади охопили лише чверть завдань державної політики сприяння розвитку громадянського суспільства. Незначними $є$ результати по таких завданнях, як підтримка волонтерства, підвищення рівня громадянської та правової культури; удосконалення умов залучення інститутів громадянського суспільства до надання соціальних послуг за рахунок бюджетних коштів; забезпечення належного правового регулювання для реалізації різних форм місцевої демократії; розвиток соціального діалогу. У результаті держава витрачає додаткові кошти на надто обтяжливі для неї функції i втрачає довіру населення" [15, с. 38].

Таким чином, першочергові завдання державної політики сприяння розвитку громадянського суспільства мають передбачати забезпечення сприятливого політико-правового середовища для його інституціонального розвитку, активне залучення громадськості (громадських об’єднань) до публічної політики, процесів вироблення та ухвалення важливих державно-управлінських рішень, формування та реалізації державної та місцевої політики. За такого підходу "державну політику сприяння розвитку громадянського суспільства» можна 
визначити як комплекс стратегічних завдань і цілеспрямованих заходів, що реалізуються органами державної влади з метою створення або удосконалення умов i можливостей для впливу громадян на розвиток держави і суспільства, вирішення соціальних проблем, задоволення ними власних інтересів та потреб" [3, с. 60]. При цьому головними принципами державної політики сприяння розвитку громадянського суспільства в Україні М. Канавець визначає забезпечення іiі ефективності та збалансованості, прозорості та врахування громадської думки і позиції громадських, благодійних, релігійних організацій, недержавних аналітичних центрів та науково-дослідних установ [8, с. 163].

У свою чергу Л. Родченко зазначає, що "сучасний підхід все більше акцентує увагу на необхідності визнання пріоритетності таких принципів, як: природні права індивіда, свобода, достаток, щастя громадян, право опору несправедливим законам, поділ влади, свобода преси, верховенство закону, тимчасові обмеження на здійснення виконавчої та законодавчої влади тощо. Ці принципи неминуче сприятимуть формуванню й розвитку Української соціальної держави та набуттю нею специфічних ознак, а саме: подолання відчуження особистості від влади; перетворення держави в соціально відповідальний інструмент громадянського суспільства, що здійснює активну соціальну політику в інтересах усіх категорій та верств населення на основі принципів відкритості, прозорості, демократичності влади, соціальної справедливості, згоди, взаємовигідного співробітництва та соціального партнерства" [13, с. 142].

На думку фахівців громадянське суспільство в Україні має таку ж невисоку спроможність, як і державні органи. Тому "розвиток взаємозв'язку та взаємодії громадянського суспільства та органів державної влади в сучасній Україні потребує: створення сприятливого конституційного та законодавчого середовища для подальшого розвитку, реалізації та захисту права на звернення громадян до органів державної влади, право кожного на правову допомогу тощо; конституційного закріплення засад реальної участі членів громадянського суспільства у всіх видах безпосереднього здійснення влади народом; спрощення участі громадськості у прийнятті державно-владних рішень, у тому числі через удосконалення процедури участі громадськості у формування та реалізації політики на всіх рівнях; здійснення громадського контролю за діяльністю органів публічної влади; державного стимулювання та підтримки механізмів соціального партнерства" [3, с. 36].

Як бачимо, одним 3 ключових моментів розвитку зрілого громадянського суспільства $\epsilon$ широке залучення громадян на постійній основі до політичного процесу та підготовки, ухвалення й реалізацій державно-управлінських рішень, налагодження ефективної взаємодії органів виконавчої влади, органів місцевого самоврядування зі структурними утвореннями політичних партій та організаціям громадянського суспільства. Така взаємодія має "базуватися на партнерстві, взаємозацікавленості у досягненні цілей, пов'язаних із процесом демократизації усіх сфер державного управління і суспільного життя, соціально-економічним i духовним прогресом, всебічним забезпеченням захисту прав і свобод людини та громадянина. На даний момент в Україні нові форми громадянської 
самоорганізації на крок випереджають готовність і здатність державних органів налагоджувати рівноправне партнерство з громадянським суспільством" [15, с. 40].

Водночас, така взаємодія неможлива без засвоєння населенням відповідних цінностей громадянської участі, утвердження в масовій політичній свідомості демократичних норм та активістських установок, спрямованих на задоволення конституційно гарантованих законних інтересів потреб та прав людини й громадянина [11, с. 282]. На нашу думку, характер ефективної взаємодії органів виконавчої влади, органів місцевого самоврядування зі структурними утвореннями політичних партій та організаціям громадянського суспільства та громадсько-політичної участі визначається такими показниками:

- політична ефективність - оцінка громадянами своєї змоги впливати на рішення влади;

- політична компетентність - наявність у громадян політичних знань та досвіду, необхідних для участі в політичному процесі;

- інтерес до політики;

- довіра громадян один до одного;

- довіра населення до громадських і державних інститутів;

- громадянська відповідальність - відчуття особистої відповідальності щодо стану суспільних справ.

Це означає, що на часі - глибоко продумана інформаційно-роз'яснювальна робота щодо наявних механізмів демократії участі та інформаційної взаємодії між органами публічної влади та суспільством [12]. Необхідним є укріплення свободи слова, оскільки далеко не останню роль в демократичних процесах відіграють засоби масової інформації, що $є$ однією 3 форм взаємодії громадянського суспільства 3 державою. ЗМІ як важлива складова інституцій громадянського суспільства виконують функції формування громадської думки, досягнення соціального консенсусу. Поєднуючи між собою віддалені та різноманітні за характером ланки суспільства через єдиний інформаційний простір, вони сприяють ідентифікації людини з референтними групами, тим самим, формуючи структуру громадянського суспільства. Вони сприяють здійсненню контролю над державною політикою, регулюванню системи стабільного розвитку суспільних відносин, участі населення в досягненні соціальної згоди. А це, зазначимо, є надзвичайно важливим у сфері формування та реалізації державної політики щодо формування зрілого громадянського суспільства.

Як зазначають автори грунтовної монографії "Громадянське суспільство: політичні та соціально-правові проблеми розвитку", громадянське суспільство i демократична держава постійно йдуть назустріч одне одному - так відбувається функція громадського діалогу з державою. Сама державність неможлива без іiі природної основи - громадянського суспільства, яке формує і легітимує всю політичну систему. Соціальна інтеграція передбачає згуртованість, об'єднання, консолідацію суспільних суб'єктів та сил в єдине ціле 3 метою досягнення спільних цілей - захисту прав і свобод людини, зміцнення державності, подолання кризи, відновлення стабільності та ін. Проте аналіз поточної політичної ситуації, публічних дискусій науковців і політиків показує: держава та 
громадські інститути нібито прагнуть одного - об'єднати українське суспільство, але розуміння механізмів соціальної інтеграції та внутрішньої взаємодії у них різне. Громадянське суспільство формулює актуальні інтереси і звертається до держави зі своїми вимогами, проханнями та ініціативами, що вимагають державної підтримки (насамперед матеріальної, правової та політичної). Держава ж може рухатися назустріч суспільству в різних формах: вивчення громадських ініціатив (їх підтримання або несхвалення), правове регулювання дії суспільних об'єднань, виділення матеріальних коштів на розвиток активності організацій, фондів, субсидії для підтримання соціально вразливих груп населення тощо. Для цього в системі структур влади функціонують спеціальні органи співпраці 3 організаціями громадянського суспільства, напрями i форми діяльності яких досить різноманітні: реєстрація цих організацій, надання їм допомоги (консультації, фінансування), створення сприятливих умов для функціонування та ін. [6, с. 65].

Українська держава здійснює послідовні, хоча й дещо запізнілі кроки в напрямку сприяння в Україні розвитку громадянського суспільства, механізмів взаємодії та співробітництва між органами публічної влади та інституціями громадянського суспільства. Так, надзвичайно важливим кроком у цьому напрямі, переконливим визнанням 3 боку управлінського прошарку нашого суспільства необхідності посилення впливу громадянського суспільства на соціально-політичні процеси, укріплення тенденцій до спроможності громадського сектору в ініціюванні нагальних реформ, діалогу 3 владою 3 гострих питань сьогодення стало затвердження Указом Президента України "Про сприяння розвитку громадянського суспільства в Україні” Національної стратегії сприяння розвитку громадянського суспільства в Україні на 2016-2020 роки [10]. Ця Стратегія накреслила основні напрямки сприяння розвитку громадянського суспільства в Україні на найближчі п'ять років, зокрема:

- створення сприятливих умов для формування та інституційного розвитку організацій громадянського суспільства;

- запровадження ефективних механізмів надання фінансової підтримки громадським ініціативам, спрямованим на реалізацію Стратегії сприяння розвитку громадянського суспільства в Україні на 2016 - 2020 рр.;

- забезпечення ефективних процедур участі громадськості під час формування та реалізації державної, регіональної політики, вирішення питань місцевого значення, зокрема, унормування на законодавчому рівні порядку проведення органами виконавчої влади, органами місцевого самоврядування консультацій з громадськістю щодо проектів нормативно-правових актів під час ï розроблення зі встановленням вичерпного переліку випадків, коли такі консультації не проводяться, та механізму запобігання порушенню вимог щодо обов'язковості таких консультацій;

- стимулювання участі організацій громадянського суспільства в соціальноекономічному розвитку України, зокрема, удосконалення механізмів фінансової підтримки стимулювання розвитку соціального підприємництва;

- забезпечення органами виконавчої влади та органами місцевого самоврядування доступу громадськості до консультацій та правової допомоги (у 
тому числі безоплатної) 3 питань порядку створення і діяльності організацій громадянського суспільства;

- розширення сфер застосування державно-приватного партнерства за участю організацій громадянського суспільства;

- проведення просвітницьких заходів та соціальної реклами 3 питань взаємодії з організаціями громадянського суспільства, розвитку громадянського суспільства [10].

Висновки. Підсумовуючи проведену розвідку, зазначимо, що в сучасному науково-практичному розумінні демократичне державотворення $є$ невіддільним від громадянського суспільства. Громадянське суспільство в концептуальному плані це, по-перше - форма людської спільності, що знаходиться на певній стадії розвитку і за допомогою праці задовольняє потреби своїх індивідів. По-друге, це - комплекс первинних об’єднань індивідів, що добровільно сформувалися (сім’”, кооперації, асоціації, господарські корпорації, громадські організації, професійні, творчі, спортивні, етнічні, конфесійні та інші об'єднання, крім державних i політичних структур). По-третє, це - система забезпечення життєдіяльності соціальної, соціокультурної та духовної сфер, їх відтворення та передачі від покоління до покоління, система самостійних та незалежних від держави громадських інститутів, які мають забезпечити умови для самореалізації окремих індивідів. та колективів, реалізації приватних інтересів та потреб, чи то індивідуальних чи колективних. Водночас не можна забувати, що громадянське суспільство — це не лише певний комплекс інститутів, а й система відносин. Воно включає систему соціальних зв'язків, у якій формуються та реалізуються економічні, професійні, культурні, релігійні та інші інтереси людей, які неможливо уявити без національних, релігійних традицій, звичаїв, міфів, символів, стереотипів поведінки, морально-етичних норм, цінностей тощо.

Сприяння всебічному розвитку громадянського суспільства $\epsilon$ важливою функцією й завданням демократичної держави, іiі органів публічного врядування в частині налагодження ефективної співпраці та взаємодії державних органів i установ з різноманітними інституціями громадянського суспільства.

\section{Jimepamypa:}

1. Андрійчук T. Державна підтримка розвитку громадянського суспільства: компаративний аналіз досвіду Албанії та України. Наукові записки Інституту політичних $i$ етнонаџіональних досліджень ім. І. Ф. Кураса НАН України. 2018. Вип. 2. С. 271-284.

2. Бондаренко Н. Становлення громадянського суспільства в Україні. Зовнішня торгівля: економіка, фінанси, право. 2018. № 2. С. 16-22.

3. Волинець С. С. Щодо визначення поняття "державна політика сприяння розвитку громадянського суспільства". Аспекти публічного управління. 2018. Т. 6, № 6-7. С. 54-63.

4. Гегель Георг Вільгельм Фрідріх. Основи філософії права, або природне право i державознавство. пер. 3 нім. Р. Осадчук, М. Кушнір ; ред. П. Соколовський. Київ : Юніверс, 2000. 329 с.

5. Гордієнко I. Л. Вплив на державну владу громадянського суспільства та інститутів безпосередньої демократії. Науковий вісник Міжнародного гуманітарного університету. Серія: Юриспрудениія. 2018. Вип. 33. С. 33-36.

6. Громадянське суспільство: політичні та соціально-правові проблеми розвитку : монографія. Г. Ю. Васильєв, В. Д. Воднік, О. В. Волянська та ін. ; за ред. М. П. Требіна. Харкі : Право, 2013. 536 с. 
7. Громадянське суспільство України: політика сприяння та залучення, виклики та трансформації. Аналітична доповідь. Офіційний сайт Національного інституту стратегічних досліджень. URL : https://niss.gov.ua/publikacii/analitichni-dopovidi/gromadyanske-suspilstvoukraini-politika-spriyannya-ta-zaluchennya

8. Канавець М. Сучасний стан і перспективи розвитку громадянського суспільства в Україні та взаємодії органів державної влади 3 громаськістю. Ефективність державного управління. 2018. Вип. 2. С. 153-168.

9. Кант Иммануил. Идея всеобщей истории во всемирно- гражданском плане; К вечному миру. Вступ. ст. и примеч. С. Ф. Ударцева. 2. изд., доп. и испр. Алматы : Жеті жарғы, 2004. 157 c.

10. Національна стратегія сприяння розвитку громадянського суспільства в Україні на 2016-2020 роки : затверджено Указом Президента України від 26 лютого 2016 року № 68/2016. Офіиійне Інтернет-представниитво Президента України. URL: https://zakon.rada.gov.ua/laws/ show/68/2016\#Text

11. Радченко О. В. Антропологічна природа ціннісної системи суспільства. Теорія та практика державного управління: Зб. наук. пр. 2008. Вип. 2 (21). С. 275 - 282.

12. Радченко О. В., Погорелий С. С. Моделювання інформаційної взаємодії між органами публічної влади та суспільством. Публічне управління : теорія та практика : зб. наук. пр. 2012. № 3(11). С. 77-85.

13. Родченко Л. М. Еволюція громадянського суспільства крізь призму історичного розвитку поняття та теорії демократії. Наукові записки Інституту законодавства Верховної Ради України. 2018. № 5. С. 138-143.

14. Родченко Л. М. Система принципів взаємовідносин органів державної влади 3 інституціями громадянського суспільства в Україні. Наукові записки Інституту законодавства Верховної Ради Украӥни. 2018. № 6. С. 154-158.

15. Турій О. В. Державна політика у сфері реалізації співпраці громадянського суспільства, органів виконавчої влади та місцевого самоврядування: правовий та управлінський аспекти. Аспекти публічного управління. 2018. Т. 6, № 6-7. С. 38-44.

\section{References:}

1. Andriychuk T. (2018). Derzhavna pidtrymka rozvytku hromadyans'koho suspil'stva: komparatyvnyy analiz dosvidu Albaniyi ta Ukrayiny [State support for the development of civil society: a comparative analysis of the experience of Albania and Ukraine]. Naukovi zapysky Instytutu politychnykh $i$ etnonatsional'nykh doslidzhen' im. I. F. Kurasa NAN Ukrayiny - Scientific notes of the Institute of Political and Ethnonational Studies. IF Kuras NAS of Ukraine. Vol. 2. 271-284. [in Ukrainian]

2. Bondarenko N. (2018). Stanovlennya hromadyans'koho suspil'stva v Ukrayini [Formation of civil society in Ukraine]. Zovnishnya torhivlya: ekonomika, finansy, pravo - Foreign trade: economics, finance, law. Vol. 2. 16-22. [in Ukrainian]

3. Volynets' S. S. (2018). Shchodo vyznachennya ponyattya "derzhavna polityka spryyannya rozvytku hromadyans'koho suspil'stva" [Regarding the definition of "state policy to promote the development of civil society"]. Aspekty publichnoho upravlinnya - Aspects of public administration. T. 6, Vol.6-7. 54-63. [in Ukrainian]

4. Hegel Georg Wilhelm Friedrich (2000). Osnovy filosofiyi prava, abo pryrodne pravo i derzhavoznavstvo [Fundamentals of philosophy of law, or natural law and political science]. Kyiv: University. 329 p. [in Ukrainian]

5. Hordiyenko I. L. (2018). Vplyv na derzhavnu vladu hromadyans'koho suspil'stva ta instytutiv bezposeredn'oyi demokratiyi [Influence of civil society and institutions of direct democracy on state power]. Naukovyy visnyk Mizhnarodnoho humanitarnoho universytetu. Seriya : Yurysprudentsiya - Scientific Bulletin of the International Humanities University. Series: Jurisprudence. Vol.33. 33-36. [in Ukrainian]

6. Vasiliev G. Yu., Vodnik V. D., Volyanskaya O. V. and others. (2013). Hromadyans'ke suspil'stvo: politychni ta sotsial'no-pravovi problemy rozvytku [Civil society: political and socio-legal problems of developmen]: monograph; for ed. M. P. Trebin. Kharkiv: Law. [in Ukrainian] 
7. Hromadyans'ke suspil'stvo Ukrayiny: polityka spryyannya ta zaluchennya, vyklyky ta transformatsiyi. (2019) Analitychna dopovid [Civil society of Ukraine: policy of assistance and involvement, challenges and transformations. Analytical report]. Official site of the National Institute for Strategic Studies. URL : https://niss.gov.ua/publikacii/analitichni-dopovidi/gromadyanskesuspilstvo-ukraini-politika-spriyannya-ta-zaluchennya [in Ukrainian]

8. Kanavets M. (2018). Suchasnyy stan i perspektyvy rozvytku hromadyans'koho suspil'stva v Ukrayini ta vzayemodiyi orhaniv derzhavnoyi vlady z hromas'kistyu [The current state and prospects of civil society development in Ukraine and the interaction of public authorities with the public]. Efektyvnist' derzhavnoho upravlinnya - Efficiency of public administration. Vol.2. 153-168. [in Ukrainian]

9. Kant Immanuil. (2004). Ideya vseobshchey istorii vo vsemirno- grazhdanskom plane; K vechnomu miru [The idea of a universal history in the world civil plan; To eternal peace]. Almaty : Zheti zharġy. [in Russian]

10. Natsional'na stratehiya spryyannya rozvytku hromadyans'koho suspil'stva v Ukrayini na 2016-2020 roky (2016) [National Strategy for Promoting the Development of Civil Society in Ukraine for 2016-2020] : approved by the Decree of the President of Ukraine of February 26, 2016 № 68/2016. Official Internet Representation of the President of Ukraine. URL: https://zakon.rada.gov.ua/laws/show/68/2016\#Text [in Ukrainian]

11. Radchenko O.V. (2008). Antropolohichna pryroda tsinnisnoyi systemy suspil'stva. [Anthropological nature of the value system of society]. Teoriya ta praktyka derzhavnoho upravlinnya - . Vol. 2 (21). 275 - 282. [in Ukrainian]

12. Radchenko O.V., Pogoreliy S. S. (2012). Modelyuvannya informatsiynoyi vzayemodiyi mizh orhanamy publichnoyi vlady ta suspil'stvom. [Modeling of information interaction between public authorities and societ]y. Publichne upravlinnya : teoriya ta praktyka. Vol 3(11). 77-85. [in Ukrainian]

13. Rodchenko L. M. (2018). Evolyutsiya hromadyans'koho suspil'stva kriz' pryzmu istorychnoho rozvytku ponyattya ta teoriyi demokratiyi [Evolution of civil society through the prism of the historical development of the concept and theory of democracy]. Naukovi zapysky Instytutu zakonodavstva Verkhovnoyi Rady Ukrayiny - Scientific notes of the Institute of Legislation of the Verkhovna Rada of Ukraine. Vol. 5. 138-143. [in Ukrainian]

14. Rodchenko L. M. (2018). Systema pryntsypiv vzayemovidnosyn orhaniv derzhavnoyi vlady z instytutsiyamy hromadyans'koho suspil'stva $\mathrm{v}$ Ukrayini [System of principles of relations of public authorities with civil society institutions in Ukraine]. Naukovi zapysky Instytutu zakonodavstva Verkhovnoyi Rady Ukrayiny - Scientific notes of the Institute of Legislation of the Verkhovna Rada of Ukraine. Vol. 6. 154-158. [in Ukrainian]

15. Turiy O. V. (2018). Derzhavna polityka u sferi realizatsiyi spivpratsi hromadyans'koho suspil'stva, orhaniv vykonavchoyi vlady ta mistsevoho samovryaduvannya: pravovyy ta upravlins'kyy aspekty [State policy in the field of cooperation of civil society, executive bodies and local selfgovernment: legal and administrative aspects]. Aspekty publichnoho upravlinnya-Aspects of public administration. T. 6, Vol. 6-7. 38-44. [in Ukrainian] 